\title{
The Latin American path towards digitization
}

\author{
Raul L. Katz, Pantelis Koutroumpis, Fernando Callorda
}

\begin{abstract}
Digitization is defined as the social transformation triggered by the massive adoption of digital technologies to generate, process, share and transact information. This paper presents a methodology followed to calculate the Digitization Index, a concept originally developed by Booz \& Company, the global management-consulting firm. This index consists of six elements capturing Ubiquity, Affordability, Reliability, Speed, Usability and Skill and 24 sub-indicators measuring tangible parameters of perceived digitization metrics. The index indicates that countries are clustered as Digitally Constrained, Emerging, Transitional or Advanced, with varying degree of contribution of digitization to economic growth. The Index is used to assess the situation of Latin American countries in terms of their progression to digitally advanced societies. In this context, the areas to focus in the formulation of Latin America digital agenda are outlined
\end{abstract}

Kerwords: academic field, epistemology, science, discipline, interdisciplinary.

\section{Introduction}

Technological revolutions are marked by innovations that shape industrial production and drive long-term economic growth. The ongoing revolution, often called the "Digital Era", builds on the advancements of information and communications technologies and shares common characteristics with other major leaps in recent history. Until now, most indices that measure progress towards this new era have focused primarily on metrics such as wireless telephony penetration, access to the Internet and broadband adoption. We argue that these indices, even those that are more comprehensive in scope (Network 
Readiness Index by the World Economic Forum, or the Digital Opportunity Index by the International Telecommunication Union) capture only a portion of the ongoing transformations. In particular, the transition to digitally intensive societies is associated not only with technology adoption, but also with the use of these technologies (e.g. new applications and services), the quality and capacity of networks, and their affordability.

The Digitization Index represents an attempt to quantitatively measure cross-country progress along the digitization development path. This index consists of six elements and 24 indicators measuring tangible parameters of perceived digitization metrics, namely Ubiquity, Affordability, Reliability, Speed, Usability and Skill. This index allows for an initial ranking and, subsequently, a more meaningful clustering of national economies into different categories. Based on the total index score and the components' scores, countries are labeled as digitally Constrained, Emerging, Transitional or Advanced. The key identifiers of each category are explained in detail resulting in a suggestive policy approach on the necessary changes required for the advancement from one category to another.

After introducing the Digitization Index, the ranking of 184 countries around the world is provided (chapter 2). In this context, an in-depth view of the state of digitization among Latin American countries is presented (chapter 3). The objective is not only to understand how Latin American stands when compared with other regions of the world, but also to understand how the region has made progress over time, and underline the areas of policy focus going forward (chapter 4). In addition, the paper provides an assessment of digitization to economic growth. It reviews models developed to assess the economic impact of digitization, both at the general level, and within each country cluster (chapter 5). On this basis, the contribution of digitization to the economic development of Latin America is estimated (chapter 6).

\section{The digitization index}

The concept of digitization has principally been pioneered by Booz \& Company, the global management-consulting firm, through a number of research pieces (Friedrich et al., 2011a; Friedrich et al, 2011b; Raad, 2011). While most of the research literature measuring adoption of ICT focuses on discrete technology platforms, we argue that the holistic adoption and usage of information technology results in enhanced effects that go beyond the contribution of specific platforms ${ }^{1}$. Furthermore, to achieve a significant impact, digitization has to be widely adopted within the economic and social fabric of a given country. Along these lines, the Digitization Index quantifies the cumulative effect

1 Perhaps a good analogy to this hypothesis is the case of the first and second Industrial Revolutions, where dramatic productivity improvements resulted from the combined effects of deployment of transportation infrastructure (roads, canals), the introduction of first steam and then internal combustion engines, the commoditization of energy, and changes in manufacturing processes. 
of adoption and usage of information and communication technologies, once they are widely utilized by individuals, economic enterprises and societies, embedded in processes of delivery of goods and services (e.g. eCommerce), and relied upon to deliver public services (e.g. education, eHealth, eGovernment).

While the digitization process and the relevant policies are rarely orchestrated through a holistic framework (South Korea represents a classic case where ex-ante prodigitization policy outgrew local demand for these services), there are several milestones identified that accelerate or impede its progress. In particular, network access and the ubiquity of access media is perhaps, the first step towards achieving a basic level of digital infrastructure in a country. The existence of network equipment without wireless or wired infrastructure has limited meaning and use. Therefore ubiquity is the first component that allows individuals and enterprises to have universal access to digital services and applications.

Beyond the deployment of networks, subscribers never adopt a technology immediately. Mass adoption starts to appear once the technologies mature and access prices fall. This is frequently accelerated by mandates for network sharing, deployment of alternative platforms or the auctioning of spectrum bands. The concept of affordability is therefore crucial for the digitization process. The existence of affordable network links is the basis for launching new applications, services and pervasive information exchange.

Internet and mobile networks have been developed based on a series of protocols that guarantee a level of quality in the services provided on the application layer. Nevertheless most access media require vast investments to perform reliably. In terms of broadband access, national network links (undersea/transoceanic cables, city-level/ country-level internet exchanges and backbone infrastructure) and 'last mile' connections are crucial for the overall network performance. For mobile access, population and land coverage, as well as the quality of links between the base stations critically affect the service delivery. The concept of network reliability is considered a key element of the digitization process as it may hinder adoption and prevent the use of applications that depend on isochronicity, latency and lag.

Network throughput, or as usually mentioned, speed is by definition important for network access. Simple applications like voice and email usage require basic access speeds but others (multimedia and video applications, cloud services, etc.) depend on higher speeds. Effectively digitization should also be measured upon network speeds.

Once the technical requirements are in place, affordable, ubiquitous, reliable and high-speed networks serve individuals and firms. The importance of this infrastructure derives from everyday activities and depends on the applications that people actually use. Services can provide information to active and passive users. For example, the user reviews posted at information portals represent a passive mode of information retrieval. Other services require active engagement, like blogging, social media, and online shopping or e-government applications. All these parameters of digitization form the concept of 
usability. Mere existence of the networks and terminals (mobiles, tablets, laptops, readers, computers or servers) is just not enough. Usability transforms the 'dummy binaries' into meaningful elements of our lives.

Lastly, people are key in shaping social transformations. The education level of each society, its beliefs and institutions has a significant effect on the online 'culture' that it will create. While parts of the online elements are globalized, the applications that affect people are usually location specific and target majorities. Technical skill is therefore a crucial metric of the ability of individuals to incorporate digital services in their lives and businesses.

These six elements combined shape the adoption path to social digitization. They are composed of several subcomponents that allow to proxy their effects on each layer. A detailed analysis of the elements and the methodology followed to calculate the index is included in appendix.

The calculation of the Digitization Index for 184 countries in 2011 reveals that countries tend to follow four clearly development stages (see Katz and Koutroumpis, 2012b). The high cluster includes Advanced countries, the medium Transitional, the low Emerging and the very low Constrained (see figure 1).

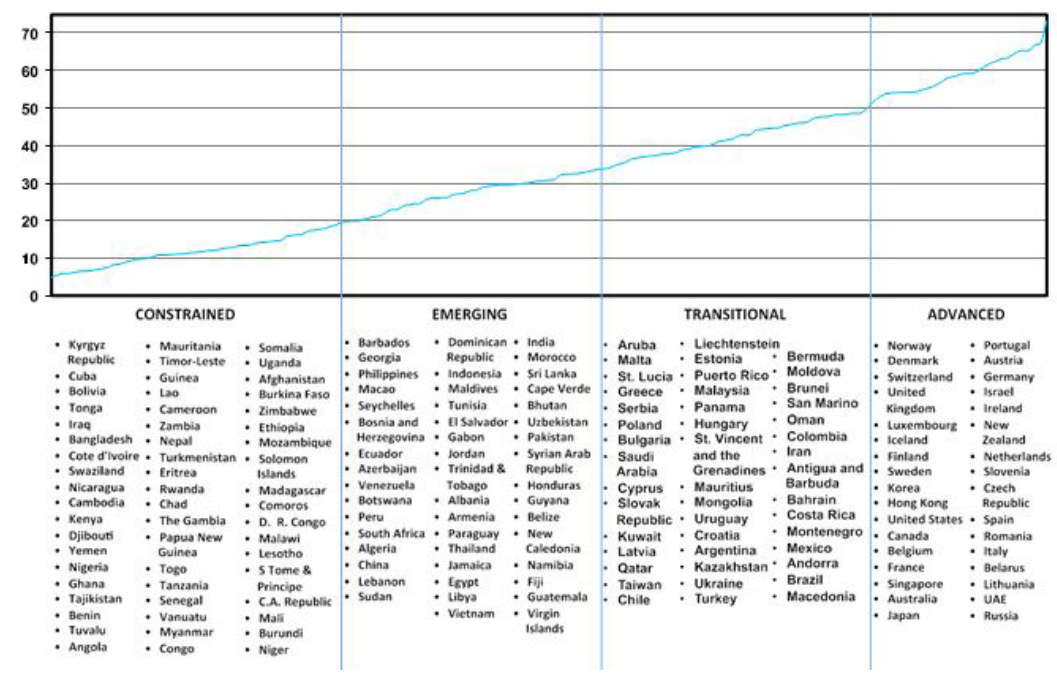

Figure 1: Four clusters of Digitization (2011)

Constrained economies-those with a digitization score below 20-face challenges in realizing basic digitization building blocks such as widespread access and affordability. 
In these nations, services remain expensive and limited in reach.

Emerging economies - those with a score between 20 and 35 - largely have addressed the affordability challenge and have achieved significant progress in providing affordable and widespread access. However, the reliability of services in emerging digitization nations remains below par and capacity is limited. Usability remains low, with online commerce constituting less than 0.5 percent of the total retail market.

Transitional is the next digitization stage, encompassing those countries with a digitization score in the range of 35 to 50 . Countries in the transitional stage have addressed the reliability challenge, providing citizens with access to ubiquitous, affordable and reasonably reliable services. Alongside, the jump in reliability, transitional countries show minor advances in the speed, usability and skill indices.

Advanced is the most mature stage of digitization, achieved with a score greater than 50 . These countries have made significant strides in addressing ICT usability and developing a talent base to take advantage of available technologies, products, and services, while improving the speed and quality of digital services.

As expected, the average and range of level of digitization varies significantly by region (see table 1). It is also striking that index variation is often higher within each region than across regions (Africa, Asia/Pacific).

\begin{tabular}{|c|c|c|c|c|}
\hline & $\begin{array}{c}\text { Number } \\
\text { of } \\
\text { Countries }\end{array}$ & $\begin{array}{c}\text { Index (Average } \\
\text { weighted by } \\
\text { Population) }\end{array}$ & Minimum & Maximum \\
\hline North America & 3 & 62.02 & 39.85 & 62.10 \\
\hline Western Europe & 20 & 58.51 & 39.14 & 73.69 \\
\hline Eastern Europe & 20 & 44.88 & 29.19 & 54.55 \\
\hline East Asia \& Pacific & 22 & 32.85 & 10.29 & 63.21 \\
\hline Middle East \& North Africa & 22 & 30.83 & 15.76 & 56.05 \\
\hline Latin America \& Caribbean & 30 & 34.63 & 17.70 & 48.82 \\
\hline Sub-Saharan Africa & 42 & 12.42 & 4.86 & 42.96 \\
\hline CIS \& Russia & 11 & 42.40 & 12.24 & 53.80 \\
\hline South Asia & 14 & 24.63 & 7.91 & 29.67 \\
\hline TOTAL & 184 & 32.13 & 6.17 & 73.69 \\
\hline
\end{tabular}

Table 1. Regional ranking of the Digitization index (2011)

The cross-country comparison of the Digitization Index allows drawing several key findings. Countries follow four states: constrained, emerging, transitional, and advanced. Digitization development varies markedly by region of the world. All OECD and middleincome countries have successfully addressed the access and affordability challenge, indicating that the digital divide, especially for middle-income countries, relies in tackling reliability and usage. The affordability and capacity components tend to rapidly drop at 
low GDP levels, indicating a big gap between mature and low-income countries.

\section{The state of digitization in latin america}

Having introduced the concept of digitization and reviewed its overall development by continent, we will now turn to examine the situation in Latin America. As indicated in table 4 above, Latin America and the Caribbean exhibit an average digitization index of 34.63. However, it is important to point out that the average masks a wide divergence across countries (see table 2).

\begin{tabular}{|c|c|c|}
\hline Stage & Country & Index \\
\hline \multirow{4}{*}{ Transitional } & Chile & 45.33 \\
\cline { 2 - 3 } & Panama & 44.29 \\
\cline { 2 - 3 } & Uruguay & 42.78 \\
\cline { 2 - 3 } & Argentina & 41.32 \\
\cline { 2 - 3 } & Colombia & 38.33 \\
\cline { 2 - 3 } & Costa Rica & 37.33 \\
\cline { 2 - 3 } & Mexico & 37.05 \\
\cline { 2 - 3 } & Brazil & 36.61 \\
\hline \multirow{5}{*}{ Emerging } & Ecuador & 32.75 \\
\cline { 2 - 3 } & Venezuela & $32.60 *$ \\
\cline { 2 - 3 } & Peru & 32.20 \\
\cline { 2 - 3 } & Dominican Republic & 29.93 \\
\cline { 2 - 3 } & El Salvador & 29.56 \\
\cline { 2 - 3 } & Paraguay & 28.68 \\
\cline { 2 - 3 } & Honduras & $22.98 *$ \\
\hline \multirow{5}{*}{} & & \\
\hline
\end{tabular}

* Computed out of 5 rather than 6 components due to missing data

Table 2. Level of Digitization (2011)

As table 2 indicates, there are no advanced digitization countries in the region, although Chile appears to be close to achieving that level. Furthermore, eight countries belong to the transitional category: Chile, Panama, Uruguay, Argentina, Colombia, Costa Rica, Mexico and Brazil in that order. Seven countries are placed in the emerging category: Ecuador, Venezuela, Peru, Dominican Republic, El Salvador, Paraguay and Honduras. Finally, three countries (Cuba, Bolivia and Nicaragua) pertain to the constrained category. 
As table 2 indicates, there are no advanced digitization countries in the region, although Chile appears to be close to achieving that level. Furthermore, eight countries belong to the transitional category: Chile, Panama, Uruguay, Argentina, Colombia, Costa Rica, Mexico and Brazil in that order. Seven countries are placed in the emerging category: Ecuador, Venezuela, Peru, Dominican Republic, El Salvador, Paraguay and Honduras. Finally, three countries (Cuba, Bolivia and Nicaragua) pertain to the constrained category.

Additionally, the digitization index across Latin American countries indicates a second level of country clustering within the transitional and emerging levels: a transitional "advanced", and an emerging "advanced" levels. For example, within the emerging level, Venezuela, Ecuador, and Peru are on the verge of reaching the transitional stage, while the remaining countries remain at the lower end of the distribution. Each cluster of countries exhibits a fairly consistent score at the digitization component level (see table 3 ).

\begin{tabular}{|c|c|c|c|c|c|c|c|}
\hline Cluster & $\begin{array}{l}\text { Digitization } \\
\text { Index }\end{array}$ & Affordability & $\begin{array}{c}\text { Infrastructure } \\
\text { Reliability }\end{array}$ & $\begin{array}{l}\text { Network } \\
\text { Access }\end{array}$ & Capacity & Usage & $\begin{array}{l}\text { Human } \\
\text { Capital }\end{array}$ \\
\hline $\begin{array}{c}\text { Transitional } \\
\text { Advanced (Chile, } \\
\text { Panama, Uruguay, } \\
\text { Argentina) }\end{array}$ & $\begin{array}{c}41.32-45.33 \\
(43.43)\end{array}$ & $\begin{array}{c}87.00-91.09 \\
(88.92)\end{array}$ & $\begin{array}{c}5.76-15.96 \\
(11.21)\end{array}$ & $\begin{array}{c}51.13- \\
56.67 \\
(52.93)\end{array}$ & $\begin{array}{c}30.06- \\
47.74 \\
(42.26)\end{array}$ & $\begin{array}{l}39.55- \\
48.19 \\
(44.08)\end{array}$ & $\begin{array}{l}12.09- \\
26.88 \\
(21.16)\end{array}$ \\
\hline $\begin{array}{c}\text { Transitional } \\
\text { (Colombia, Costa } \\
\text { Rica, Mexico, } \\
\text { Brazil) }\end{array}$ & $\begin{array}{c}36.61-38.33 \\
(37.33)\end{array}$ & $\begin{array}{c}85.96-91.62 \\
(88.25)\end{array}$ & $\begin{array}{l}5.50-9.08 \\
(7.47)\end{array}$ & $\begin{array}{c}37.91- \\
49.86 \\
(42.92)\end{array}$ & $\begin{array}{c}29.73- \\
37.53 \\
(34.29)\end{array}$ & $\begin{array}{c}31.05- \\
34.11 \\
(32.70)\end{array}$ & $\begin{array}{l}9.82-26.45 \\
(18.36)\end{array}$ \\
\hline $\begin{array}{c}\text { Emerging } \\
\text { Advanced } \\
\text { (Ecuador, } \\
\text { Venezuela, Peru) }\end{array}$ & $\begin{array}{c}32.20-32.75 \\
(32.52)\end{array}$ & $\begin{array}{c}73.33-90.71 \\
(79.66)\end{array}$ & $\begin{array}{c}1.64-9.30 \\
(5.17)\end{array}$ & $\begin{array}{c}42.55- \\
47.05 \\
(45.16)\end{array}$ & $\begin{array}{c}6.30-28.46 \\
(15.03)\end{array}$ & $\begin{array}{c}23.43- \\
42.23 \\
(31.62)\end{array}$ & $\begin{array}{c}19.74- \\
35.68 \\
(27.71)\end{array}$ \\
\hline $\begin{array}{c}\text { Emerging (D. } \\
\text { Republic, E1 } \\
\text { Salvador, Paraguay, } \\
\text { Honduras) }\end{array}$ & $\begin{array}{c}22.98-29.93 \\
(27.79)\end{array}$ & $\begin{array}{c}60.10-85.49 \\
(73.27)\end{array}$ & $\begin{array}{c}3.39-14.12 \\
(7.83)\end{array}$ & $\begin{array}{c}35.26- \\
42.72 \\
(40.41)\end{array}$ & $\begin{array}{c}5.13-12.09 \\
(8.36)\end{array}$ & $\begin{array}{c}21.19- \\
35.20 \\
(26.22)\end{array}$ & $\begin{array}{c}9.11-19.12 \\
(14.20)\end{array}$ \\
\hline $\begin{array}{l}\text { Constrained (Cuba, } \\
\text { Bolivia, Nicaragua) }\end{array}$ & $\begin{array}{c}17.70-19.87 \\
(19.14)\end{array}$ & $\begin{array}{c}32.85-54.32 \\
(43.70)\end{array}$ & $\begin{array}{l}2.09-2.48 \\
(2.28)\end{array}$ & $\begin{array}{c}26.85- \\
41.56 \\
(36.37)\end{array}$ & $\begin{array}{c}1.17-13.73 \\
(6.67)\end{array}$ & $\begin{array}{c}16.81- \\
19.38 \\
(17.97)\end{array}$ & $\begin{array}{c}10.71- \\
15.06 \\
(12.88)\end{array}$ \\
\hline
\end{tabular}

Note: The first two values are the minimum and maximum, while the number between parentheses is the mean.

Table 3. Digitization Sub-Indicators by Cluster (2011)

The range of the scores by component provides a basis to determine the key challenges faced by each of the country clusters. The transitional "advanced" countries have successfully tackled the affordability and, to some degree, the network access challenge. Hurdles remain primarily in the infrastructure reliability and human capital domains, and secondarily, within usage and network capacity. On the other hand, the emerging "advanced" countries urgently face challenges in infrastructure reliability, capacity, usage, and human capital. This analysis provides a fairly targeted assessment of digitization development targets across the region (see table 4). 


\begin{tabular}{|c|c|c|c|}
\hline Cluster & Targets fulfilled & $\begin{array}{c}\text { Primary } \\
\text { Development } \\
\text { Targets }\end{array}$ & $\begin{array}{l}\text { Secondary Develo- } \\
\text { pment Targets }\end{array}$ \\
\hline $\begin{array}{l}\text { Transitional "Ad- } \\
\text { vanced" (Chile, } \\
\text { Panama, Uruguay, } \\
\text { Argentina) }\end{array}$ & $\begin{array}{l}\text { - Affordability } \\
\text { - Network access }\end{array}$ & $\begin{array}{l}\text { - Infrastructure } \\
\text { reliability } \\
\text { - Human capital }\end{array}$ & $\begin{array}{l}\text { - Usage } \\
\text { - Network capacity }\end{array}$ \\
\hline $\begin{array}{l}\text { Transitional (Co- } \\
\text { lombia, Costa Rica, } \\
\text { Mexico, Brazil) }\end{array}$ & - Affordability & $\begin{array}{l}\text { - Infrastructure } \\
\text { reliability } \\
\text { - Human capital } \\
\text { - Network capacity }\end{array}$ & $\begin{array}{l}\text { - Network access } \\
\text { - Usage }\end{array}$ \\
\hline $\begin{array}{l}\text { Emerging "Ad- } \\
\text { vanced" (Ecuador, } \\
\text { Venezuela, Peru) }\end{array}$ & - Affordability & $\begin{array}{l}\text { - Infrastructure } \\
\text { reliability } \\
\text { - Human capital } \\
\text { - Network capacity } \\
\text { - Usage }\end{array}$ & - Network access \\
\hline $\begin{array}{l}\text { Emerging (D. Re- } \\
\text { public, El Salvador, } \\
\text { Paraguay, Honduras }\end{array}$ & & $\begin{array}{l}\text { - Infrastructure } \\
\text { reliability } \\
\text { - Human capital } \\
\text { - Network capacity } \\
\text { - Usage }\end{array}$ & $\begin{array}{l}\text { - Affordability } \\
\text { - Network access }\end{array}$ \\
\hline $\begin{array}{l}\text { Constrained (Cuba, } \\
\text { Bolivia, Nicaragua) }\end{array}$ & & $\begin{array}{l}\text { - Affordability } \\
\text { - Infrastructure } \\
\text { reliability } \\
\text { - Human capital } \\
\text { - Network capacity } \\
\text { - Usage } \\
\text { - Network access }\end{array}$ & \\
\hline
\end{tabular}

Table 4. Digitization development targets by cluster

As the targets in table 7 indicate, the two dominant imperatives across the region are infrastructure reliability and human capital. This would imply, first, that the level of investment in ICT in Latin America is not commensurate to the achievements in network access (e.g. penetration). This could mean that, unless investment is not increased, network saturation will aggravate as a result of both penetration and usage. Additionally, human capital remains a persistent need to support the development of increasingly digitized societies. 
It is important to mention that, while affordability appears to be a less important target overall it does not necessarily mean that pricing of all services is at affordable levels. Since the affordability component comprises pricing data for wireline, wireless, and broadband, affordable wireless tariffs have a positive impact on the overall value of the affordability component.

\section{Assessing the latin american path to digitization}

How fast is the Latin American region moving towards advanced stages of digitization? Is the rate of change similar to that of other emerging economies? Figure 2 shows the evolution of the average digitization index for all regions around the world.

\begin{tabular}{|c|c|c|c|c|c|c|c|}
\hline Cluster & $\begin{array}{l}\text { Digitization } \\
\text { Index }\end{array}$ & Affordability & $\begin{array}{c}\text { Infrastructure } \\
\text { Reliability }\end{array}$ & $\begin{array}{l}\text { Network } \\
\text { Access }\end{array}$ & Capacity & Usage & $\begin{array}{l}\text { Human } \\
\text { Capital }\end{array}$ \\
\hline $\begin{array}{c}\text { Transitional } \\
\text { Advanced (Chile, } \\
\text { Panama, Uruguay, } \\
\text { Argentina) }\end{array}$ & $\begin{array}{c}41.32-45.33 \\
(43.43)\end{array}$ & $\begin{array}{c}87.00-91.09 \\
(88.92)\end{array}$ & $\begin{array}{c}5.76-15.96 \\
(11.21)\end{array}$ & $\begin{array}{c}51.13- \\
56.67 \\
(52.93)\end{array}$ & $\begin{array}{c}30.06- \\
47.74 \\
(42.26)\end{array}$ & $\begin{array}{c}39.55- \\
48.19 \\
(44.08)\end{array}$ & $\begin{array}{c}12.09- \\
26.88 \\
(21.16)\end{array}$ \\
\hline $\begin{array}{c}\text { Transitional } \\
\text { (Colombia, Costa } \\
\text { Rica, Mexico, } \\
\text { Brazil) }\end{array}$ & $\begin{array}{c}36.61-38.33 \\
(37.33)\end{array}$ & $\begin{array}{c}85.96-91.62 \\
(88.25)\end{array}$ & $\begin{array}{l}5.50-9.08 \\
(7.47)\end{array}$ & $\begin{array}{c}37.91- \\
49.86 \\
(42.92)\end{array}$ & $\begin{array}{c}29.73- \\
37.53 \\
(34.29)\end{array}$ & $\begin{array}{c}31.05- \\
34.11 \\
(32.70)\end{array}$ & $\begin{array}{l}9.82-26.45 \\
(18.36)\end{array}$ \\
\hline $\begin{array}{c}\text { Emerging } \\
\text { Advanced } \\
\text { (Ecuador, } \\
\text { Venezuela, Peru) }\end{array}$ & $\begin{array}{c}32.20-32.75 \\
(32.52)\end{array}$ & $\begin{array}{c}73.33-90.71 \\
(79.66)\end{array}$ & $\begin{array}{l}1.64-9.30 \\
(5.17)\end{array}$ & $\begin{array}{l}42.55- \\
47.05 \\
(45.16)\end{array}$ & $\begin{array}{c}6.30-28.46 \\
(15.03)\end{array}$ & $\begin{array}{c}23.43- \\
42.23 \\
(31.62)\end{array}$ & $\begin{array}{c}19.74- \\
35.68 \\
(27.71)\end{array}$ \\
\hline $\begin{array}{c}\text { Emerging (D. } \\
\text { Republic, El } \\
\text { Salvador, Paraguay, } \\
\text { Honduras) }\end{array}$ & $\begin{array}{c}22.98-29.93 \\
(27.79)\end{array}$ & $\begin{array}{c}60.10-85.49 \\
(73.27)\end{array}$ & $\begin{array}{c}3.39-14.12 \\
(7.83)\end{array}$ & $\begin{array}{c}35.26- \\
42.72 \\
(40.41)\end{array}$ & $\begin{array}{c}5.13-12.09 \\
(8.36)\end{array}$ & $\begin{array}{l}21.19- \\
35.20 \\
(26.22)\end{array}$ & $\begin{array}{c}9.11-19.12 \\
(14.20)\end{array}$ \\
\hline $\begin{array}{l}\text { Constrained (Cuba, } \\
\text { Bolivia, Nicaragua) }\end{array}$ & $\begin{array}{c}17.70-19.87 \\
(19.14)\end{array}$ & $\begin{array}{c}32.85-54.32 \\
(43.70)\end{array}$ & $\begin{array}{l}2.09-2.48 \\
(2.28)\end{array}$ & $\begin{array}{c}26.85- \\
41.56 \\
(36.37)\end{array}$ & $\begin{array}{c}1.17-13.73 \\
(6.67)\end{array}$ & $\begin{array}{c}16.81- \\
19.38 \\
(17.97)\end{array}$ & $\begin{array}{c}10.71- \\
15.06 \\
(12.88)\end{array}$ \\
\hline
\end{tabular}

Figure 2. Regional Digitization Index (2004-2011)

As figure 2 shows, Latin America has been increasing its level of digitization at a compound annual growth rate of 6.48\% since 2004, a level comparable to East Asia \&t Pacific (5.63\%) and Eastern Europe (7.84\%). However, since 2010, digitization has increased dramatically in the region. At $10.42 \%$ growth year on year, Latin America is the second fastest growing region, behind Africa. However, even at that rate, given the starting base and growth rate of the developed world, it is apparent that, unless a dramatic change in policy initiatives is set in motion, the region will not be able to catch up with the developed world.

To determine potential policies that could be beneficial to the development of digitization in Latin America, we will now turn to assessing the impact of individual country experience and practices. For this purpose, it is necessary to examine the path followed by specific Latin American countries in reaching their current stage. Do all countries in 
the region follow a gradual, consistent developmental path toward digitization, or are there any idiosyncratic features (e.g. speed of digitization growth, leap-frogging) that can be linked to either structural variables (e.g. the composition of the economy, the level of economic development) or policy initiatives (e.g. the implementation of a national digital agenda)? In other words, are there any policy initiatives that have proven successful in furthering the development of digitization of countries in the region? In order to identify the initiatives, the scores of the index for the period 2004-2011 for all Latin American countries were calculated.

At first view, the transitional countries in Latin America exhibit a consistent, yet gradual, change in levels of digitization (see figure 3).

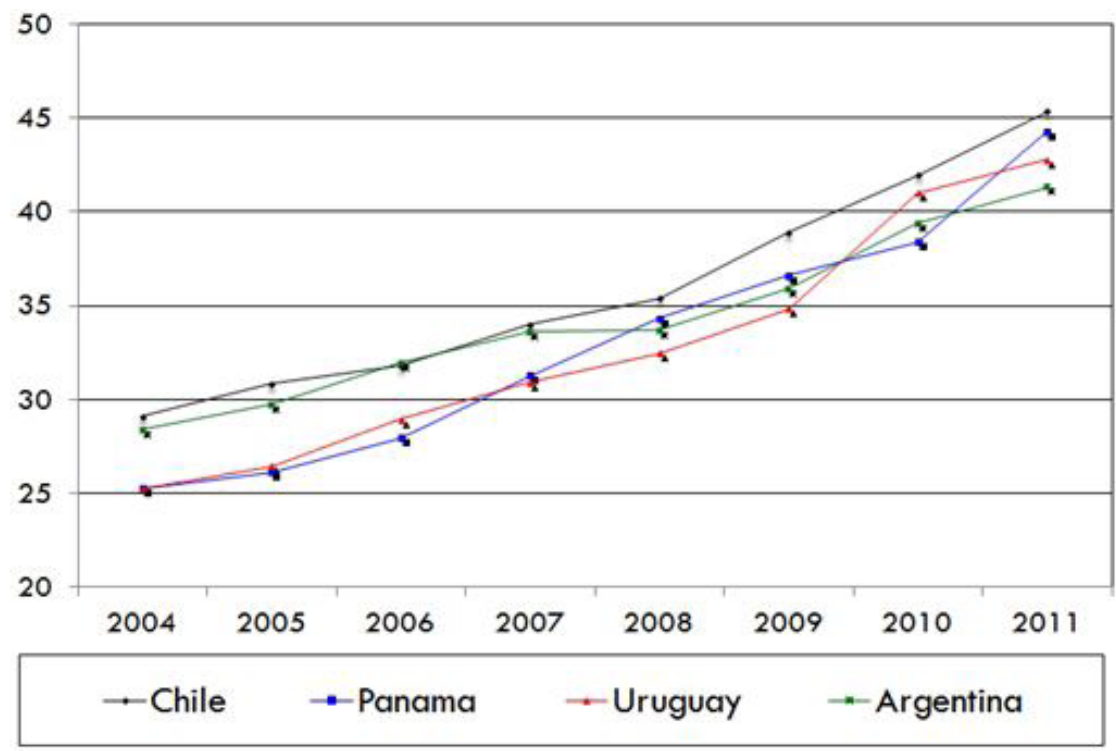

Figure 3. "Advanced" Transitional Countries: Comparative Evolution of Digitization (2004-2011)

As figure 3 indicates, all transitional countries have consistently increased their digitization level over the past eight years, following a convergent growth pattern. Along these lines, the rate of increase varies from country to country. For example, while Chile increased its index by ten points over the eight-year period, Panama and Uruguay witnessed a 15-point increase since 2004, and Argentina's index grew by approximately 15 points since that same year. Can these paths be linked to a specific policy initiative implemented in each country? Chile started focusing on the development of the country's digitization in 2007 with the launch of its first iteration of the Digital Agenda. The focused set of prodigitization policies resulted in an acceleration of the index driven by device and service 
penetration, as well as the speed of broadband access. In the case of Uruguay, this country has been gradually increasing its digitization index, although a surge occurred in 2009 when the country deployed a direct data transmission link to the United States, which increased international bandwidth ten-fold. This was coupled with the implementation of a massive broadband and ICT initiative, focused on the education sector. Argentina, on the other hand, benefits substantially from a significant improvement of the economy that took place in after 2008, combined with an increase in broadband bandwidth, which yielded an augmentation of Internet adoption. These variables were stimulated as well by the impact of the national broadband plan "Argentina Conectada". Finally, Panama achieved a substantial improvement in the affordability index due to a strong decline of wireless prices. In 2010, Panama also benefitted from the deployment of an international data transmission link that almost doubled the capacity of other countries such as Argentina. To sum up, the two common levers that have substantially impacted digitization in "advanced" transitional countries are the formulation of a national digital/broadband agenda, and, in particular, the deployment of international transmission data links.

Turning now to the other transitional countries, the convergent trend is even clearer with the ramp-up of Colombia and Brazil (see figure 4).

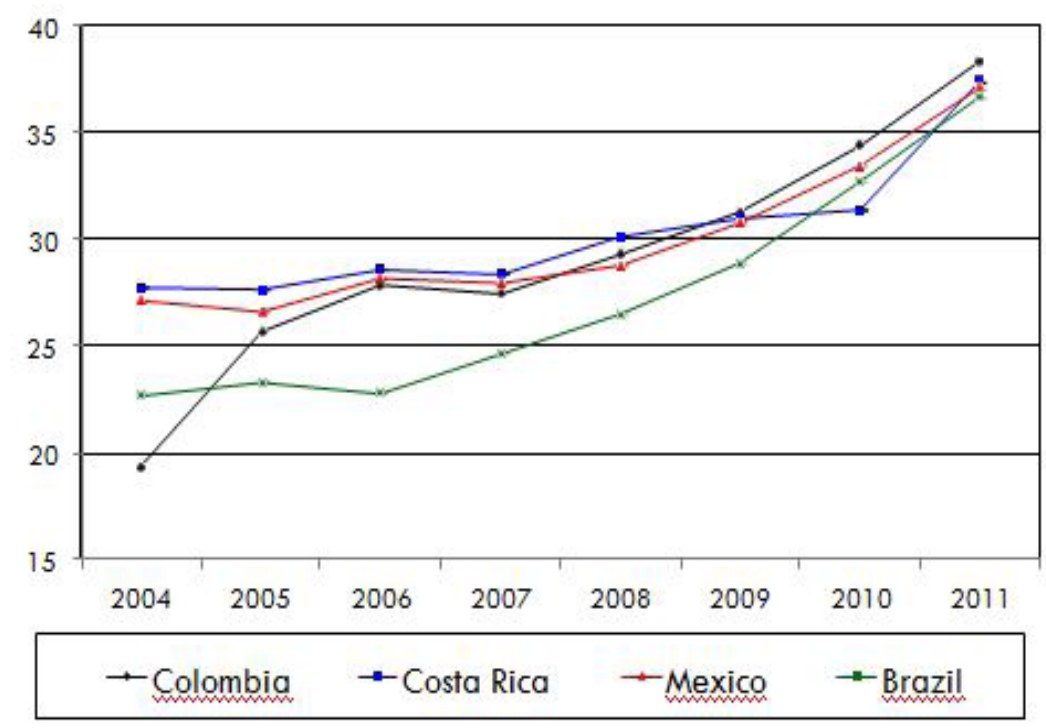

Figure 4. Transitional Countries: Comparative Evolution of Digitization (2004-2011)

These countries have all increased their digitization index primarily driven by an 
improvement in the affordability index. For example, Colombia witnessed in 2004 a $50 \%$ reduction of the wireline installation fee, and a 75\% decline of a pre-paid call prices. Driven by the elasticity of demand derived from this price decline, the digitization index jumped 7 points as a result of increasing adoption. This is why after 2005 the dominant improvement in Colombia registered in the network access component. Likewise, in Brazil, the improvement in digitization was driven by wireless price declines generated by enhanced competition, and the broadband price reduction as a result of the introduction of the "Popular Bandwidth Plan" prompted by the National Broadband Plan. In Costa Rica, the ramp-up in digitization occurred in 2011, when wireless market liberalization led to a significant increase in wireless broadband penetration. Mexico, on the other hand, did not show a significant change in the digitization components in this period, except for an important increase in broadband speed in 2010.

In the case of Emerging Digitization Countries, the convergence trend is also apparent, with one exception (see figure 5).

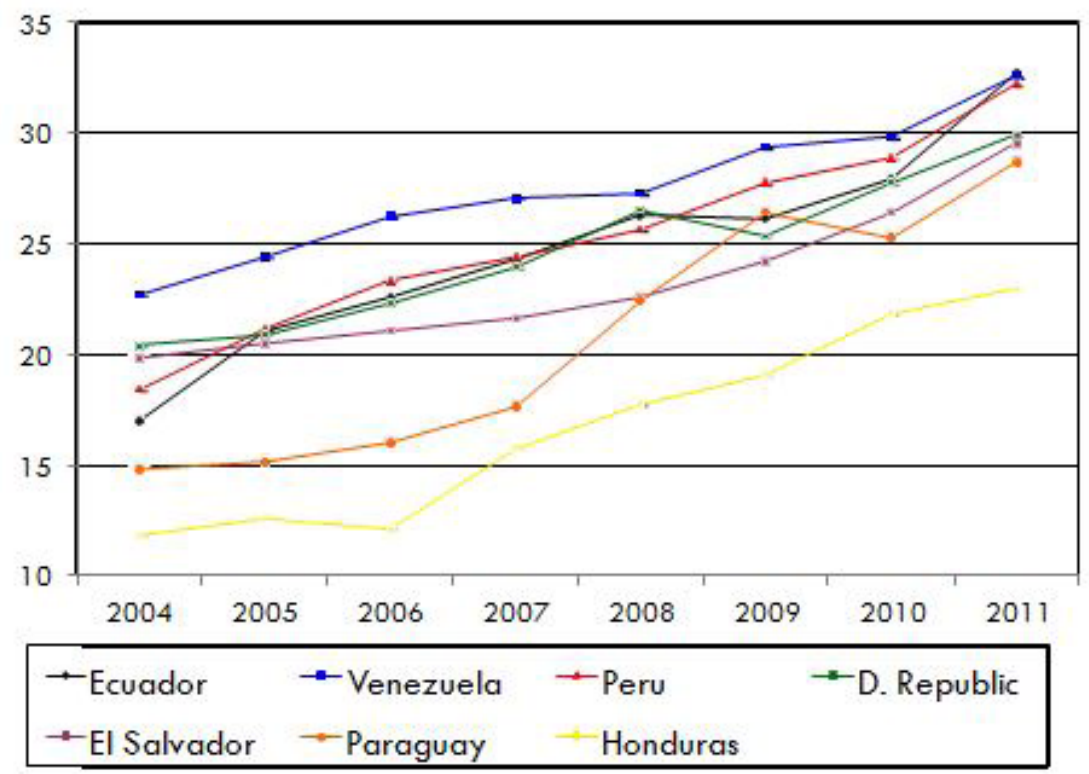

Figure 5. Emerging Countries: Comparative Evolution of Digitization (2004-2011)

The dominant factor in the improvement in digitization of emerging countries is the increase in network access driven by price reductions, combined with some country- 
specific factors. For example, Ecuador increased its index by 15 points in eight years as a result of price declines and an increase in international broadband capacity. Peru also registered a price decline, coupled with an increase in average broadband speeds. Similarly, Paraguay also exhibited a constant decrease in tariffs, although that was combined with an improvement in wireless non-voice usage. This was also the case of Venezuela. Honduras, on the other hand, improved its position mainly through an increase in wireless adoption, both voice and broadband.

Convergence is also the trend in constrained Latin American countries (see figure 6)

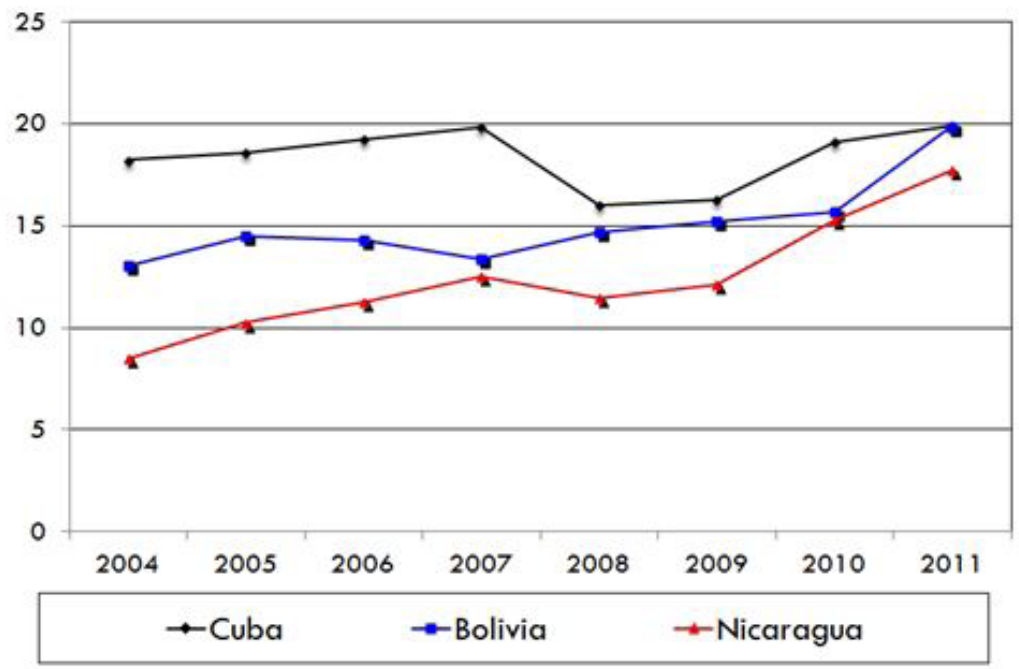

Figure 6. Constrained Countries: Comparative Evolution of Digitization (2004-2011)

No common factor is driving the increase in digitization among constrained Latin America countries. For example, while Cuba has wireless coverage of $80 \%$, service penetration is practically nil. On the other hand, Bolivia's index has been improving as a result of the low tariffs of wireless broadband, while Nicaragua is improving digitization by virtue of wireless penetration.

In conclusion, while all Latin American countries are increasing their digitization index, they appear to follow different paths to digitization. "Advanced" Transitional countries, having tackled the affordability and network access hurdles, continue progressing by emphasizing international connectivity and the implementation of national broadband/ digital agendas/plans. The remaining transitional countries improve their digitization level primarily by emphasizing the affordability lever. Emerging countries are improving 
their digitization performance as a result of an increase in network access driven by price reductions, while digitally constrained countries are marginally improving through the increase of wireless adoption, a basic building block.

When it comes to rate of digitization growth, "advanced" transitional countries follow a gradual progression, albeit at a lower rate than other transitional countries. In general terms, more digitally advanced countries tend to grow their digital infrastructure at a rate slower than the less advanced countries, a convergence effect. For example, while transitional countries grew their digitization index by $6.81 \%$ between 2004 and 2011, emerging grew at a CAGR of 7.83\% ${ }^{1}$. However, as will be shown below, the economic contribution of digitization in countries with higher level of development is greater because of the structure of their economies.

Some Latin American countries, such as Panama, Uruguay, and Colombia undergo quantum leap changes (close to 20 points in eight years) in digitization triggered by specific policy initiatives, such as telecom market liberalization with spill-over impact on the ICT eco-system, a combination of active government involvement and private sector participation, and centralized state planning. A second tier of fast growing digitization countries (15 points in eight years) includes Chile, Brazil, Ecuador, Peru, and Paraguay.

Data analysis indicates that the pace of digitization and movement between stages is accelerating at a rapid pace. Countries such as Chile, Panama, Uruguay and Argentina took nearly five years on average to move from the emerging to the transitional stage (between 2004 and 2009). If they continue growing at the same rate, they would be the first cluster of countries in the region to reach the advanced stage in 2014. On the other hand, of the countries that in 2004 had a constrained status, Colombia was the only one that leap-frogged to the transitional stage in 2011. Most of the other constrained countries could only move to the emerging stage (Ecuador, El Salvador, Paraguay, Peru and Honduras), and lastly some of them made no significant progress between 2004 and 2011 (Cuba, Bolivia and Nicaragua).

Overall, the rate of change of the index across countries indicates a gradual acceleration in the development of digitization in the region. Between 2004 and 2007, of the 18 Latin American countries under analysis only four moved one stage (from the constrained level to the emerging level); in the ensuing four-year period of 2007 to 2011, 10 countries progressed to the next level of digitization development ( 8 from the emerging to the transitional, and 2 from the constrained to the emerging level). From 2004 to 2007, the average growth in the digitization score was four points. From 2007 through 2011, the average jump was eight points. Lastly, only Colombia experienced a two stage jump in the period from 2004 to 2011.

The acceleration stems from a number of factors. The region now can follow the path that developed nations already blazed, learning from their best practices. They also

1 The digitization index for constrained countries grew at 6.19\%, since they are confronted with very basic problems such as increasing wireless penetration. 
can take advantage of mature technologies and markets, and the resulting price reductions. Furthermore, the acceleration between stages may derive from increased market liberalization, growing affordability of technologies, growing availability of skills, and the government plans to develop ICT in the region. In sum, Latin America is moving toward higher stages of digitization at an ever-increasing pace.

\section{Socio-economic impact of digitization}

Similarly to what has been estimated for wireless telephony and broadband technology (Czernich et al; 2011, Koutroumpis 2009; Gruber and Koutroumpis 2011; Katz 2012; Katz and Koutroumpis, 2012), digitization is expected to have an impact on the economy. To test this hypothesis, an endogenous growth model that links Gross Domestic Product to the Fixed Stock of Capital, Labor Force and the Digitization index as a proxy of technology progress was constructed for 151 countries (see Katz and Koutroumpis, 2012b). This model for economic output stems from the simple Cobb-Douglas form: $Y=$ $A(t) K 1-b L b$ where $A(t)$ represents the level of technology progress (in our case the Digitization Index), $\mathrm{K}$ corresponds to the

fixed capital formation and $L$ to the labor force.

$$
\text { (1) } \log \left(G D P_{i t}\right)=\operatorname{allog}\left(K_{i t}\right)+\operatorname{a2} \log \left(L_{i t}\right)+\operatorname{a3} \log \left(D_{i t}\right)+E i t
$$

The index is a weighted average of different indicators that might be endogenous to GDP, like broadband and mobile penetration. However their impact on the metric - these two metrics combined account for $5 \%$ of the index - seems insignificant. Additionally it is hard to find an instrument that could possibly control for this effect. Given the small effect we expect it has on GDP we extended the analysis controlling for country and year fixed effects to help mitigate potential problems and account for the heterogeneity of our sample (Table 5$)$.

\begin{tabular}{lc}
\hline$G D P\left(G D P_{\text {it }}\right)$ & \\
Fixed Capital Stock $\left(\mathrm{K}_{\text {it }}\right)$ & $0.1632 * * *$ \\
Labor $\left(\mathrm{L}_{\text {it }}\right)$ & $0.1406 * * *$ \\
Digitization Index $\left(\mathrm{D}_{\text {it }}\right)$ & $0.0814 * * *$ \\
Constant & $18.23 * * *$ \\
\hline Year Effects & YES \\
Country Effects & YES \\
\hline Observations & 783 \\
\hline $\mathrm{R}^{-s q u a r e d}$ & 0.9051 \\
& \\
$* * *$ denote statistical significance at the $1 \%$ level
\end{tabular}

${ }^{* * *}$ denote statistical significance at the $1 \%$ level 
Table 5. Economic Impact of Digitization

All variables are significant at the $1 \%$ level. As expected, the capital formation is positive. Labor contribution to GDP is also consistent; quality is often crucial in this case but the overarching concept is largely accepted. The Digitization Index is found to have a positive effect indicating a strong effect on economic output. Our calculations suggest that there is a measureable input from digitization on country level growth both on a direct level and indirectly. This is captured by the different components of the metric that help measure the existence of network infrastructure and their affordability to the use of social media and online retail performance'.

From a quantitative standpoint this estimate is also valuable. A ten-point increase in the Digitization Index ${ }^{2}$ has approximately a 3\% impact on GDP for the period 2004-2011 resulting on an annualized effect of $0.44 \% .{ }^{3}$ These effects are higher than the ones found in earlier works for broadband penetration ${ }^{4}$. For example Koutroumpis (2009) estimated an annualized effect of $0.24 \%$ on GDP growth for a 10 point increase in broadband adoption for a European sample between 2002 - 2007, while Katz et al. (2010) found a contribution of $0.23 \%$ for Germany, and Gruber and Koutroumpis (2011) found a 0.20\% for wireless telephony for the period 1990-2007. We believe the higher impact results from the fact that Digitization is a rather holistic approach compared to previous works, as it allows to estimate the actual contribution on GDP from a combined infrastructure, capacity, skill, quality and usage point. This significant finding stipulates that full economic impact ICT is achieved through the cumulative adoption of all technologies, in addition to the assimilation and usage in the production and social fabric. Achieving broadband penetration is only one aspect of required policies; maximization of economic impact can only be achieved through a holistic set of policies ranging from telecoms to computing to adoption of Internet and eCommerce. In a monetary equivalent, the impact of a 10 point increase is a 1.8 trillion added output on the world economy.

Given this estimate, one would be interested to explore whether economic contribution is also related to the level of digitization. This relates to the hypothesis of increasing

1 Given that the digitization index is a proxy for technological progress, and considering some of the indicators used to construct the digitization index, we tested for the presence of collinearity between the index and the other covariates, relying on the variance decomposition proportions in Belsey et al. (1990). The test for collinearity indicates that the sample lies close to the threshold suggested by the literature. In particular our model has a condition number of 32 , whereas the concern levels, according to Belsey et al. start with condition numbers above 30 .

2 A ten-point increase would generate a growth of the digitization index from an average value of 27 to 37 . The $37 \%$ increase by the impact effect of 0.0814 generates a $3.01 \%$ impact on GDP

3 We use as a base case of an 'average' country whose Digitization Index increased by 10 points.

4 Annual Growth Rate (CAGR) attributed to digitization derives from formula (1):

$C A G R=\left[\left(\frac{\frac{\text { Digitization }_{2011}}{100-\text { Digitization }_{2011}-\text { Digitization }_{2004}}}{\frac{\text { Digitization }_{2011}}{100-\text { Digitization }_{2004}}}\right) * \hat{a}_{3}+1\right]^{1 / 7}$ 
returns to scale in network technologies as the new markets and spillover effects contribute to this phenomenon. The initial idea is that countries with lower scores are often the ones that lack basic access, skills and usage that would prevent them from experiencing important effects on their economies. For this purpose, the sample of 151 countries was broken into four different clusters. Four dummy variables were created (high, medium, low and very low) that take the value of 1 if the country is within the Digitization scores of interest or 0 if not. For the advanced cluster the threshold is 50 , for the transitional 35-50, for the emerging 20-35 and for the constrained 0-20.

Returning to the model used in equation (1), it is now transformed to account for this scalable approach. The new model is:

(2) $\log \left(G D P_{i t}\right)=a_{1} \log ($ Kit $)+a_{2} \log \left(L_{i t}\right)+h i g h * \log \left(D_{i t}\right)+m e d * \log \left(D_{i t}\right)+$ low $* \log \left(D_{i t}\right)+$ vlow $* \log \left(D_{i t}\right)+E_{i t}$

\section{GDP (GDPit)}

$\begin{array}{ll}\text { Fixed Capital Stock (Kit) } & 0.1595^{* * *} \\ \text { Labor (Lit) } & 0.1338^{* * *} \\ \begin{array}{l}\text { Digitization (Dit) } \\ \text { High (Advanced) }\end{array} & 0.0681^{* * *} \\ \text { Medium (Transitional) } & 0.0777^{* * *} \\ \text { Low (Emerging) } & 0.0774^{* * *} \\ \text { Very Low (Constrained) } & 0.0751^{* * *} \\ \text { Constant } & 18.28^{* * *} \\ \text { Year Effects } & \text { YES } \\ \text { Country Effects } & \text { YES }\end{array}$

Observations 783

R-Squared within $\quad 0.9036$

*** denote statistical significance at the $1 \%$ level

Table 6. Estimates on the Scalable Economic Impact of Digitization

The results presented in Table 6 are a confirmation of the increasing returns hypothesis, although they might also indicate that decreasing returns start to emerge at the advanced level of digitization. The advanced countries' cluster has a less pronounced effect on economic output compared to the transitional and emerging groups. This could indicate that the advanced countries could be at the beginning of a new innovation process that could yield even larger impact on the economy. 
On the other hand, Transitional and Emerging stages are very closely tied and rather distinct from the constrained clusters. Evidently, there is still considerable heterogeneity within these clusters that might have an impact on the results. Nevertheless, the picture is quite clear from a macro perspective: there is indeed a scalable approach in this process and the returns appear to be largely increasing after a score in the region of 30 , with a saturation point emerging at around 50 .

From a quantitative standpoint this estimate is also valuable. A ten-point increase in the Digitization Index has the following impact:

- Advanced 2.52\% compound impact on GDP for the period 2004-2011 results on an annualized effect of $0.36 \%$

- Transitional: 2.88\% compound impact on GDP for the period 2004-2011 results on an annualized effect of $0.41 \%$

- Constrained: $2.87 \%$ compound impact on GDP for the period 2004-2011 yields an annualized effect of $0.40 \%$

- Emerging: 2.78\% compound impact on GDP for the period 2004-2010 leads to an annualized effect of $0.39 \%$

By relying on the coefficients calculated for the worldwide sample, the impact of digitization on the Latin American economies has been quantified.

Between 2008 and 2011, the Latin American region (17 countries considered) grew USD 1.289 trillion (the difference at current USD between 4.199 trillion and 5.488). At the same time, the growth in digitization in Latin American economies contributed to an increase of USD 116 billion. As a result, it is estimated that the share of growth in the GDP that can be attributed to digitization is 9.03\%. For the period between 2010 and 2011 , the share of GDP growth is 7.40\%. These estimates represent a strong evidence of the economic relevance of digitization and the importance of adopting strong pro- digitization policies in the region.

\section{Conclusion}

To sum up, the digitization index represents a powerful instrument to measure not only the deployment and adoption of information technologies in a discrete fashion, but to incorporate usage processes, representing the holistic dimension of impact. Along these lines, the Latin American region appears to be moving relatively fast in terms of increasing its level of digitization. However, as mentioned above, the aggregate regional rate masks a substantial divergence across countries, with some on the verge of attaining "advanced" status (Chile, Panama, Argentina and Uruguay, in particular), while others remain well below the transitional status. At the same time, the analysis indicates the 
importance of adopting pro-digitization policies for leap-frogging developmental stages. AS an example, Colombia propelled itself from a constrained status in 2004 to transitional in 2011, increasing 19 points in eight years.

Secondly, the challenges facing each cluster of countries are of a different nature. The transitional "advanced" countries have successfully tackled the affordability (primarily wireless, less so in broadband) and, to some degree, the network access challenge. Hurdles remain primarily in the infrastructure reliability and human capital domains, and secondarily, within usage and network capacity. On the other hand, the emerging "advanced" countries urgently face challenges in infrastructure reliability, capacity, usage, and human capital, while emerging countries need to focus on all levers of digitization.

Thirdly, the index also allows the identification of specific developmental paths towards digitization. In this context, some countries exhibit a higher rate of digitization change than the rest of the region. In particular, Argentina, Chile, Colombia, Panama, and Uruguay appear to be the regional "fast movers". The speed of change in all of these countries is driven by the adoption of specific pro-digitization policies.

Fourthly, digitization appears to have a higher contribution to economic growth than discrete technologies. This points out to a multiplying factor that captures the enhanced impact of a developed technology eco-system. The econometric models allow the estimation of the economic contribution of digitization. In the case of Latin America, it is estimated that the share of growth in the GDP between 2008 and 2011 that can be attributed to digitization is $9.03 \%$.

The public policy implications of these findings for Latin America are several. First, the enhanced impact of digitization vis- à-vis broadband requires tackling the formulation of ICT policies in a comprehensive and holistic manner, covering all areas of the eco-system. This drives the need to insert broadband planning within the larger ICT infrastructure and usage context provided by digital agendas. Secondly, digitization policies need to initially focus on affordability (for example, achieve broadband monthly fee/GDP per capita $<0.12$ ), and access (targeting, as minimum, $22 \%$ broadband penetration, at least $70+\%$ of population using a PC, and $40 \%$ penetration of broadband wireless). However, policies need to complement the deployment of networks, by emphasizing usage, targeting to reach $15 \%$ of eCommerce transactions/retail, an eGovernment web measurement index higher than 30, and Internet adoption higher than 30\%. Fourth, countries that aim at achieving a quantum leap in digitization (20 points rise of the index in five years) need to combine four levers: telecom market liberalization with spill-over impact on eco-system, usage promotion policies, a combination of active government involvement and private sector participation, and centralized convergent state planning. Fifth, digitization promotion policies need to be combined with industrial sector related policies aimed at generating the spill-over ICT impact on economic growth and job creation. 


\section{References}

Belsey, D.A., Kuh, E. and Welsch, R. (1990). Regression Diagnostics: Identifying Influential Data and Sources of Collinearity. New York: Wiley

Czernich, N., Falck, O., Kretschmer T., \& Woessman, L. (2011), 'Broadband infrastructure and economic growth', Economic Journal, 121(552), 505-532

Freeman, C. and Perez, C. (1988), 'Structural crises of adjustment, business cycles and investment behavior', in G.Dosi, C. Freeman, R. Nelson, G. Silverberg and L. Soete (eds), Technical Change in the Twenty-first Century, London: Pinter.

Friedrich, R., LeMerle, M., Peterson, M., and Koster, A. (2011a). The next wave of digitization: setting your direction, building your capabilities. Dusseldorf: Booz \& Company

Friedrich, R., Le Merle, M., Grone, F. and Koster, A. (2011b). Measuring Industry Digitization: Leaders and Laggards in the Digital Economy. Dusseldorf: Booz \& Company

Gruber and Koutroumpis, P. (2011) "Mobile Telecommunications and the impact on Economic Development". Economic Policy, Vol. 67, 1-41.

Katz, R. (2012). The Impact of Broadband on the Economy: Research to date and Policy Issues. International telecommunication Union, The impact of Broadband on the Economy Broadband Series, Geneva, Switzerland.

Katz, R. and Koutroumpis, P. (2012a). 'The Economic Impact of Telecommunications in Senegal', Communications and Strategies 86, 2nd Quarter

Katz, R. and Koutroumpis, P. (2012b). Measuring socio-economic digitization: a paradigm shift. Columbia Institute for Tele- Information Working Paper.

Koutroumpis, P. (2009). "The Economic Impact of Broadband on Growth: A Simultaneous Approach". Telecommunications Policy, 33, 471-485.

Landes, D. S. (1969) The Unbound Prometheus: Technological change and industrial development in Western Europe from 1750 to the present, Cambridge: Cambridge University Press 
Nardo, M., Saisana, M., Saltelli, A., Tarantola, S., Hoffman, A., \&t Giovannini, E. (2005). Handbook on constructing composite indicators: Methodology and user guide. OECD Statistics Working Papers no. 2005/3, OECD. Retrieved from /http://www.oecd.org/LongAbstract/0,2546,en_2649_34257_35231682_119684_1_1_1,00. html.

Nye, D. E. (1990), Electrifying America, Cambridge, MA: MIT Press

Perez C (2004) 'Technological revolutions, paradigm shifts and socio-institutional change' in Globalization, economic development and inequality: an alternative perspective, Erik S. Reinert, Edward \&t Elgar Publishing

Raad, H. (2011). Digitizing MENA economies. Dubai: Booz \& Company

Sabbag. K., Friedrich, R., El-Darwiche, B., Singh, M., Ganediwalla, S. and Katz, R. (2012) 'Maximizing the Impact of Digitization", Dutta, S. and Bilbao-Osorio, B. (eds.) The Global Information Technology Report 2012. Geneva: World Economic Forum and Insead.

\section{Appendix: methodology for calculating the digitization index}

The Digitization Index is comprised of six components and 24 indicators (see table A.1.)

\begin{tabular}{|c|c|c|}
\hline Indicators & Components & Sub-components \\
\hline \multirow[t]{5}{*}{ Affordability } & \multirow{2}{*}{$\begin{array}{l}\text { Residential fixed line cost } \\
\text { adjusted for GDP } \\
\text { per capita }\end{array}$} & $\begin{array}{l}\text { Residential fixed line tariff ( } 3 \text { minute call to a fixed line at peak rate) } \\
\text { adjusted for GDP per capita }\end{array}$ \\
\hline & & Residential fixed line connection fee adjusted for GDP per capita \\
\hline & \multirow[t]{2}{*}{$\begin{array}{l}\text { Mobile cellular cost a djusted } \\
\text { for GDP per capita }\end{array}$} & $\begin{array}{l}\text { Mobile cellular prepaid tariff ( } 1 \text { minute call off-net at peak rate) adjusted } \\
\text { for GDP/capita }\end{array}$ \\
\hline & & $\begin{array}{l}\text { Mobile cellular prepaid one-time connection fee adjusted for GDP } \\
\text { per capita }\end{array}$ \\
\hline & $\begin{array}{l}\text { Fixed broadband Intemet } \\
\text { access cost adjusted for } \\
\text { GDP per capita }\end{array}$ & Monthly residential price for a fixed broadband connection \\
\hline \multirow{3}{*}{$\begin{array}{l}\text { Infrastructure } \\
\text { reliability }\end{array}$} & \multirow{3}{*}{$\begin{array}{l}\text { Investment per } \\
\text { telecom subscriber } \\
\text { (mobile, } \\
\text { broadband and fixed) }\end{array}$} & Mobile investment per telecom subscriber \\
\hline & & Broadband investment per telecom subscriber \\
\hline & & Fixed line investment per telecom subscriber \\
\hline \multirow{3}{*}{$\begin{array}{l}\text { Network } \\
\text { Access }\end{array}$} & \multirow[t]{2}{*}{ Network penetration } & Fixed Broadband penetration per household \\
\hline & & Mobile Phone penetration \\
\hline & Other venetration metrics and & 3G/4G Penetration \\
\hline
\end{tabular}




\begin{tabular}{|l|l|l|}
\hline \multirow{4}{*}{ Capacity } & coverage infrastructure & Mobile broadband penetration \\
\cline { 3 - 3 } & & PC Population penetration \\
\cline { 3 - 3 } & $\begin{array}{l}\text { Intemational Intemet } \\
\text { bandwidth }\end{array}$ & Intematle cellular network coverage \\
\cline { 2 - 3 } & Broadband speed & Broadband speed (Peak Mbps, Average Mbps) \\
\hline \multirow{4}{*}{ Usage } & Intemet retail & Intemet retail as percent of total retail \\
\cline { 2 - 3 } & e-Govemment & E-govemment Web measure index \\
\cline { 2 - 3 } & Individuals using the intemet & Percentage of individuals using the Intemet \\
\cline { 2 - 3 } & $\begin{array}{l}\text { Non-voice services as \% of } \\
\text { wireless ARPU }\end{array}$ & $\begin{array}{l}\text { Non-voice (data, message, VAS) spending as percentage of wireless } \\
\text { ARPU }\end{array}$ \\
\cline { 2 - 3 } & &
\end{tabular}

\begin{tabular}{|c|c|c|}
\hline & \multirow[t]{3}{*}{ coverage infrastructure } & Mobile broadband penetration \\
\hline & & PC Population penetration \\
\hline & & Mobile cellular network coverage \\
\hline \multirow[t]{2}{*}{ Capacity } & $\begin{array}{l}\text { Intemational Intemet } \\
\text { bandwidth }\end{array}$ & Intemational Intemet bandwidth (kbps/user) \\
\hline & Broadband speed & Broadband speed (Peak Mbps, Average Mbps) \\
\hline \multirow[t]{6}{*}{ Usage } & Intemet retail & Intemet retail as percent of total retail \\
\hline & e-Govemment & E-govemment Web measure index \\
\hline & Individuals using the intemet & Percentage of individuals using the Intemet \\
\hline & $\begin{array}{l}\text { Non-voice services as } \% \text { of } \\
\text { wireless ARPU }\end{array}$ & $\begin{array}{l}\text { Non-voice (data, message, VAS) spending as percentage of wireless } \\
\text { ARPU }\end{array}$ \\
\hline & Social network visitors & Dominant Social Network Unique Visitors per month Per Capita \\
\hline & SMS usage & SMS usage per subscriber \\
\hline \multirow[t]{2}{*}{ Human Capital } & Engineers & Engineers as a percentage of total population \\
\hline & Skilled Labor & $\begin{array}{l}\text { Labor force with more than a secondary education as a percentage of the } \\
\text { total labor force }\end{array}$ \\
\hline
\end{tabular}

Table A.1: Indicators, and sub-indicators of the Digitization Index

Source: adapted from Sabbagh et al., 2012

Affordability is calculated by the relative costs of all underlying infrastructures. In this context, fixed, mobile and broadband service charges are considered together with connection fees. Each of the components (fixed, mobile and broadband) is given equal weight to account for the sample heterogeneity and the varying adoption in different socio economic conditions.

Infrastructure reliability depends on the quality of the services provided. Initially two different metrics were utilized - faults per line and investment per telecom subscriber - as quality proxies. However, during the statistical validation of the index, the first component had to be eliminated ${ }^{1}$ mainly because of the lack of an adequate number of observations. Therefore, this component is comprised of investment per telecom subscriber (in all types of networks). This metric is sensitive to front- loaded investment projects that materialize later in time; therefore it might exhibit higher values before societies actually receive the implied benefit.

Network access derives from the adoption of mobile and fixed broadband networks. While adoption is always lower than network coverage or access, telecommunications operators usually invest in areas where higher adoption is expected. Nevertheless, regu1 The factor analysis is explained in the next section 
latory interventions may incentivize network coverage in rural or underutilized areas as a means of reducing the digital divide. To account for this phenomenon, overall mobile coverage is also used, coupled with PC ownership and mobile broadband penetration. These metrics correct the potential underestimation of mobile or fixed broadband adoption and reflect the actual network access in different socio-economic contexts ${ }^{2}$.

The measurement of Network Capacity is based on two different sources: international network links and "last mile" network service offerings. International bandwidth is crucial in order to provide adequate throughput to remote sites. This metric controls for the common phenomenon of several emerging regions of the world that experience high connection speeds for local content and services only (usually through hybrid Ethernet networks), while access to remote sites is constrained by either economic or technology bottlenecks. Additionally, we account for the percent of connections that deliver higher than 2 Mbps of service.

Usage is a key component of digitization. We utilize variables ranging from the percentage of online retail versus traditional retail commerce, e-Government services, the percent of individuals that report some kind of internet usage (especially for countries that connections are not necessarily dedicated), social media adoption and usage (a metric that reflects both the social and the economic benefits realized primarily by advertising campaigns), SMS usage (a simple data proxy) and the percent of total mobile connection revenues per user that are dedicated to data services only. All these variables shed light in different usage patterns and help understand how these values range across a wide variation of income, educational and social contexts.

Human capital contributes to digitization and is affected by it. However, existing conditions or country fixed effects help shape the capacity, focus and speed of services that will be offered. This process depends both on the numbers of people that can offer them (proxied by technical staff or engineers) and by the qualities and skills of the people using them. Therefore in this metric we combine the impact of digitization on its suppliers and its target audience.

The various sources of data used to create the Digitization Index are included in Table A.2.

\footnotetext{
2 For example, in Senegal mobile penetration was almost 80\% in 2011 and fixed broadband access less than 1\%. Nevertheless, mobile broadband coverage exceeds $30 \%$, almost 30 times higher than actual broadband usage. Therefore the network access is already there but the adoption metrics fail to reflect it. On the other hand, fixed broadband coverage is almost impossible to measure. This is why fixed broadband adoption is used as a proxy of this variable (See Katz and Koutroumpis, 2012).
} 


\begin{tabular}{|c|c|c|}
\hline $\begin{array}{l}\text { Name of } \\
\text { indicator }\end{array}$ & Description of Indicator & Source \\
\hline \multirow[t]{5}{*}{ Affordability } & $\begin{array}{l}\text { Residential fixed line tariff ( } 3 \text { minute call to a fixed line at peak rate) adjusted for } \\
\text { GDP per capita }\end{array}$ & \multirow{5}{*}{ ITU } \\
\hline & Residential fixed line connection fee adjusted for GDP per capita & \\
\hline & $\begin{array}{l}\text { Mobile cellular prepaid tariff (1 minute call off-net at peak rate) adjusted for } \\
\text { GDP/capita }\end{array}$ & \\
\hline & Mobile cellular prepaid one-time connection fee adjusted for GDP per capita & \\
\hline & Monthly residential price for a fixed broadband connection & \\
\hline \multirow{3}{*}{$\begin{array}{l}\text { Infrastructure } \\
\text { reliability }\end{array}$} & Mobile investment per telecom subscriber & \multirow{3}{*}{ World Bank } \\
\hline & Broadband investment per telecom subscriber & \\
\hline & Fixed line investment per telecom subscriber & \\
\hline \multirow{6}{*}{$\begin{array}{c}\text { Network } \\
\text { Access }\end{array}$} & Fixed Broadband penetration per household & \multirow[t]{2}{*}{ ITU } \\
\hline & Mobile Phone penetration & \\
\hline & 3G/4G Penetration & $\begin{array}{l}\text { Wireless } \\
\text { Intelligence }\end{array}$ \\
\hline & Mobile broadband penetration & $\begin{array}{l}\text { Wireless } \\
\text { Intelligence }\end{array}$ \\
\hline & PC Population penetration & \multirow{3}{*}{ ITU } \\
\hline & Mobile cellular network coverage & \\
\hline \multirow[t]{3}{*}{ Capacity } & Intemational Intemet bandwidth (kbps/user) & \\
\hline & Broadband speed (Peak Mbps, Average Mbps) & Akamai \\
\hline & Fixed line investment per telecom subscriber & \\
\hline \multirow{6}{*}{$\begin{array}{c}\text { Network } \\
\text { Access }\end{array}$} & Fixed Broadband penetration per household & \multirow[t]{2}{*}{ ITU } \\
\hline & Mobile Phone penetration & \\
\hline & 3G/4G Penetration & $\begin{array}{c}\text { Wireless } \\
\text { Intelligence }\end{array}$ \\
\hline & Mobile broadband penetration & $\begin{array}{l}\text { Wireless } \\
\text { Intelligence }\end{array}$ \\
\hline & PC Population penetration & \multirow{3}{*}{ ITU } \\
\hline & Mobile cellular network coverage & \\
\hline \multirow[t]{2}{*}{ Capacity } & Intemational Intemet bandwidth (kbps/user) & \\
\hline & Broadband speed (Peak Mbps, Average Mbps) & Akamai \\
\hline \multirow{6}{*}{ Usage } & Intemet retail as percent of total retail & Euromonitor \\
\hline & E-govemment Web measure index & UN \\
\hline & Percentage of individuals using the Intemet & ITU \\
\hline & Non-voice (data, message, VAS) spending as percentage of wireless ARPU & $\begin{array}{l}\text { Wireless } \\
\text { Intelligence }\end{array}$ \\
\hline & Dominant Social Network Unique Visitors per month Per Capita & Intemet World Stats \\
\hline & SMS usage per subscriber & $\begin{array}{l}\text { WCDM / Wireless } \\
\text { Intelligence / ITU }\end{array}$ \\
\hline \multirow{2}{*}{$\begin{array}{l}\text { Human } \\
\text { Capital }\end{array}$} & Engineers as a percentage of total population & UNESCO \\
\hline & $\begin{array}{l}\text { Labor force with more than a secondary education as a percentage of the total labor } \\
\text { force }\end{array}$ & World Bank \\
\hline
\end{tabular}

Table A.2: Data sources of the indicators of the Digitization Index

The Digitization Index has been constructed following a typical methodology for composite index validity assessment ${ }^{1}$. First the theoretical framework of the index is set up and the variables are selected. This includes all six components that describe the digitization process. Then a multivariate analysis is performed in order to analyze the underlying structure of the data. In particular the process helps choose the statistically valid sub-indicators in each component that are both adequately different from each other and measure accurately the latent phenomenon. This process includes the principal

1 See the OECD Handbook for constructing composite indicators by Nardo et al. (2005) 
components' and factor analysis of all components'. Data has been normalized to meet these criteria and allow for spatial and temporal comparisons. At this point, the second component of infrastructure reliability had to be dropped as it failed the factor analysis thresholds².

\begin{tabular}{|c|l|c|c|}
\hline Ranking & \multicolumn{1}{|c|}{ Country } & $\mathbf{2 0 0 4}$ & $\mathbf{2 0 1 1}$ \\
\hline 1 & Norway & 58.73 & 73.69 \\
\hline 2 & Denmark & 52.66 & 67.46 \\
\hline 3 & Switzerland & 50.34 & 67.08 \\
\hline 4 & United Kingdom & 50.54 & 65.52 \\
\hline 5 & Luxemburg & $37.81 *$ & 65.38 \\
\hline 6 & Iceland & 49.90 & 65.33 \\
\hline 7 & Finland & 45.54 & 64.36 \\
\hline 8 & Sweden & 51.08 & 63.39 \\
\hline 9 & Korea & 58.38 & 63.21 \\
\hline 10 & Hong Kong, China & 47.18 & 62.61 \\
\hline 11 & United States & 47.60 & 62.10 \\
\hline 12 & Canada & 46.39 & 61.36 \\
\hline 13 & Belgium & 47.75 & 60.11 \\
\hline 14 & France & 43.61 & 59.33 \\
\hline 15 & Singapore & 55.14 & 59.31 \\
\hline 16 & Australia & 47.69 & 59.27 \\
\hline 17 & Japan & 51.40 & 58.75 \\
\hline 18 & Portugal & 38.73 & 58.39 \\
\hline 19 & Austria & 43.49 & 57.91 \\
\hline 20 & Germany & 43.33 & 56.88
\end{tabular}

* Computed out of 5 components

Table A.3: Top-20 countries of the Digitization Index

\footnotetext{
1 Kaiser criterion and Cronbach coefficient alpha

2 Two tests were performed to assess the adequacy of the sample: the Cronbach Alpha is 0.74 and the KMO statistic 0.75 (all subcomponents above 0.71 ), allowing us to proceed with the subsequent analysis of the index. The Kaiser-Meyer-Olkin (KMO) measure of sampling adequacy is a statistic for comparing the magnitudes of the observed correlation coefficients to the magnitudes of the partial correlation coefficients. The concept is that the partial correlations should not be very large if The Digitization Index has been calculated for 184 countries and all years between 2004 and 2011. The top 20 country scores are included in Table A.3 (ranked for year 2011).
} 
Norway tops the charts, in 2004, and since 2007. In 2005 and 2006 Korea was the leader due to its high performance in the affordability and the usage scores. A cluster of countries with similar scores follows Norway: Denmark, Switzerland, United Kingdom, Luxemburg, Iceland and Finland. It is interesting to note that, when excluding United Kingd om, countries with less than 8 million of population appear in the top-7. Then Sweden, Korea, Hong Kong, United States and Canada make another closely ranked cluster. Luxemburg has made a remarkable progress in this period because the country doubled its share of broadband connections with more than $2 \mathrm{MB}$ of speed and it significantly

\begin{tabular}{|c|l|c|c|c|c|}
\hline$\#$ & Country & $\mathbf{2 0 0 4}$ & $\mathbf{2 0 1 1}$ & \\
\hline 1 & Norway & 58.73 & & 73.69 & \\
\hline 2 & Denmark & 52.66 & & 67.46 & \\
\hline 3 & Switzerland & 50.34 & 67.08 & \\
\hline 4 & United Kingdom & 50.54 & & 65.52 & \\
\hline 5 & Luxembourg & 37.81 & $*$ & 65.38 & \\
\hline 6 & Iceland & 49.90 & & 65.33 & \\
\hline 7 & Finland & 45.54 & & 64.36 & \\
\hline 8 & Sweden & 51.08 & & 63.39 & \\
\hline 9 & Korea & 58.38 & & 63.21 & \\
\hline 10 & Hong Kong SAR, China & 47.18 & & 62.61 & \\
\hline 11 & United States & 47.60 & & 62.10 & \\
\hline 12 & Canada & 46.39 & & 61.36 & \\
\hline 13 & Belgium & 47.75 & & 60.11 & \\
\hline 14 & France & 43.61 & & 59.33 & \\
\hline 15 & Singapore & 55.14 & & 59.31 & \\
\hline 16 & Australia & 47.69 & & 59.27 & \\
\hline 17 & Japan & 51.40 & & 58.75 & \\
\hline 18 & Portugal & 38.73 & & 58.39 & \\
\hline 19 & Austria & 43.49 & & 57.91 & \\
\hline 20 & Germany & 43.33 & & 56.88 & \\
\hline 21 & Israel & 49.11 & & 56.05 & $*$ \\
\hline 22 & Ireland & 42.74 & & 56.03 & \\
\hline 23 & New Zealand & 40.12 & & 55.43 & \\
\hline 24 & Netherlands & 47.07 & & 55.09 & $*$ \\
\hline 25 & Slovenia & 36.76 & & 54.55 & \\
\hline 26 & Czech Republic & 37.83 & & 54.32 & \\
\hline
\end{tabular}




\begin{tabular}{|l|l|l|l|l|l|}
\hline 27 & Spain & 42.15 & & 54.31 & \\
\hline 28 & Romania & 23.69 & & 54.28 & \\
\hline 29 & Italy & 41.15 & & 54.19 & \\
\hline 30 & Belarus & 34.69 & & 53.80 & \\
\hline 31 & Lithuania & 33.34 & & 52.99 & \\
\hline 32 & United Arab Emirates & 34.11 & & 51.82 & \\
\hline 33 & Russia & 32.20 & & 50.23 & \\
\hline 34 & Aruba & 28.32 & $*$ & 48.82 & $*$ \\
\hline 35 & Malta & 36.43 & & 48.70 & \\
\hline 36 & St. Lucia & 25.86 & $* *$ & 48.61 & \\
\hline 37 & Greece & 34.09 & & 48.36 & \\
\hline 38 & Serbia & 19.71 & & 48.31 & \\
\hline 39 & Poland & 29.67 & & 48.24 & \\
\hline 40 & Bulgaria & 27.12 & $*$ & 47.79 & \\
\hline 41 & Saudi Arabia & 29.19 & & 47.77 & \\
\hline 42 & Cyprus & 27.69 & $*$ & 47.63 & \\
\hline 43 & Slovak Republic & 28.39 & $*$ & 47.05 & \\
\hline 44 & Kuwait & 39.59 & & 46.14 & \\
\hline 45 & Latvia & 30.27 & & 46.10 & \\
\hline 46 & Qatar & 32.87 & & 45.96 & \\
\hline 47 & Taiwan, China & 30.66 & $* *$ & 45.58 & $*$ \\
\hline 48 & Chile & 29.10 & & 45.33 & \\
\hline 49 & Liechtenstein & 23.88 & $* *$ & 44.77 & $*$ \\
\hline 50 & Estonia & 34.45 & & 44.70 & \\
\hline 51 & Puerto Rico & 24.36 & $* *$ & 44.49 & $* *$ \\
\hline 52 & Malaysia & 34.75 & & 44.36 & \\
\hline 53 & Panama & 25.25 & & 44.29 & \\
\hline 54 & Hungary & 22.64 & $* *$ & 44.19 & \\
\hline 55 & St. Vincent and the Grenadines & 17.35 & $*$ & 43.37 & $* *$ \\
\hline 56 & Mauritius & 25.28 & & 42.96 & \\
\hline 57 & Mongolia & 26.67 & & 41.90 & \\
\hline 58 & Uruguay & & & \\
\hline 59 & Croatia & & \\
\hline
\end{tabular}




\begin{tabular}{|c|l|c|c|c|c|}
\hline 60 & Argentina & 28.41 & & 41.32 & \\
\hline 61 & Kazakhstan & 23.48 & & 41.25 & \\
\hline 62 & Ukraine & 25.69 & & 41.00 & \\
\hline 63 & Turkey & 24.32 & & 40.06 & \\
\hline 64 & Bermuda & 35.70 & $* *$ & 39.85 & $*$ \\
\hline 65 & Moldova & 9.34 & $*$ & 39.76 & $*$ \\
\hline 66 & Brunei & 19.28 & $* *$ & 39.67 & $*$ \\
\hline 67 & San Marino & 16.26 & $* *$ & 39.14 & $*$ \\
\hline 68 & Oman & 24.12 & & 39.01 & \\
\hline 69 & Colombia & 19.38 & & 38.33 & \\
\hline 70 & Iran & NA & & 37.92 & \\
\hline 71 & Antigua and Barbuda & 27.61 & $* *$ & 37.74 & $* *$ \\
\hline 72 & Bahrain & 26.07 & $* *$ & 37.69 & $*$ \\
\hline 73 & Costa Rica & 27.74 & & 37.33 & \\
\hline 74 & Montenegro & 13.13 & $* *$ & 37.28 & $*$ \\
\hline 75 & Mexico & 27.08 & & 37.05 & \\
\hline 76 & Andorra & NA & & 36.73 & $* *$ \\
\hline 77 & Brazil & 22.67 & & 36.61 & \\
\hline 78 & Macedonia & 23.19 & & 35.94 & \\
\hline 79 & Barbados & 28.05 & $*$ & 34.96 & $*$ \\
\hline 80 & Georgia & 18.70 & & 34.74 & \\
\hline 81 & Philippines & 25.63 & & 33.87 & \\
\hline 82 & Macao SAR, China & 30.29 & $*$ & 33.81 & $*$ \\
\hline 83 & Seychelles & 21.82 & $* *$ & 33.42 & $*$ \\
\hline 84 & Bosnia and Herzegovina & 15.06 & $*$ & 33.23 & \\
\hline 85 & Ecuador & 17.01 & & 32.75 & \\
\hline 86 & Azerbaijan & 9.22 & $* *$ & 32.75 & \\
\hline 87 & Venezuela & 22.65 & $*$ & 32.60 & $*$ \\
\hline 88 & Botswana & 18.97 & $* *$ & 32.45 & $*$ \\
\hline 89 & Peru & 18.41 & & 32.20 & \\
\hline 90 & South Africa & 20.40 & & 31.36 & \\
\hline 91 & Algeria & 17.21 & & 31.01 & \\
\hline 92 & China & 19.71 & $*$ & 30.82 & $*$ \\
\hline 93 & Lebanon & 17.18 & $* *$ & 30.59 & $*$ \\
\hline & & & & & \\
& & & & \\
\hline
\end{tabular}




\begin{tabular}{|c|l|c|c|c|c|}
\hline 94 & Sudan & 4.56 & $* *$ & 30.34 & $*$ \\
\hline 95 & Dominican Republic & 20.45 & $*$ & 29.93 & \\
\hline 96 & Indonesia & 18.85 & & 29.91 & \\
\hline 97 & Maldives & 12.28 & $* *$ & 29.67 & $* *$ \\
\hline 98 & Tunisia & 18.31 & $* *$ & 29.67 & $*$ \\
\hline 99 & El Salvador & 19.85 & $*$ & 29.56 & \\
\hline 100 & Gabon & 19.64 & $* *$ & 29.53 & $*$ \\
\hline 101 & Jordan & 18.81 & $*$ & 29.53 & \\
\hline 102 & Trinidad and Tobago & 21.97 & $* *$ & 29.36 & $* *$ \\
\hline 103 & Albania & 15.23 & & 29.19 & \\
\hline 104 & Armenia & 12.15 & $*$ & 28.92 & \\
\hline 105 & Paraguay & 14.82 & & 28.68 & \\
\hline 106 & Thailand & 17.33 & & 28.11 & \\
\hline 107 & Jamaica & 23.87 & $* *$ & 27.42 & $* *$ \\
\hline 108 & Egypt & 6.45 & $*$ & 27.20 & $*$ \\
\hline 109 & Libya & NA & & 27.03 & $* *$ \\
\hline 110 & Vietnam & 11.81 & $*$ & 26.51 & \\
\hline 111 & India & 15.54 & $*$ & 26.24 & $*$ \\
\hline 112 & Morocco & 11.97 & & 25.93 & \\
\hline 113 & Sri Lanka & 14.03 & & 25.93 & \\
\hline 114 & Cape Verde & 13.69 & $* *$ & 25.73 & $*$ \\
\hline 115 & Bhutan & 9.57 & $* *$ & 24.59 & $*$ \\
\hline
\end{tabular}

\begin{tabular}{|l|l|c|c|c|c|}
\hline 116 & Uzbekistan & 13.76 & & 24.57 & \\
\hline 117 & Pakistan & 11.36 & $*$ & 24.11 & \\
\hline 118 & Syrian Arab Republic & 12.05 & $*$ & 24.07 & \\
\hline 119 & Honduras & 11.79 & $* *$ & 22.98 & $*$ \\
\hline 120 & Guyana & 15.75 & $*$ & 22.96 & \\
\hline 121 & Belize & 11.55 & $*$ & 22.44 & \\
\hline 122 & New Caledonia & 16.61 & $* *$ & 21.84 & $* *$ \\
\hline 123 & Namibia & 19.49 & & 21.40 & \\
\hline 124 & Fiji & 12.99 & $* *$ & 21.13 & $*$ \\
\hline 125 & Guatemala & 15.30 & $* *$ & 20.86 & $*$ \\
\hline 126 & Virgin Islands & 19.11 & $* *$ & 20.42 & $* *$ \\
\hline 127 & Kyrgyz Republic & 4.56 & $*$ & 19.96 &
\end{tabular}




\begin{tabular}{|l|l|c|c|c|c|}
128 & Cuba & 18.20 & $*$ & 19.87 & \\
\hline 129 & Bolivia & 13.02 & & 19.85 & $*$ \\
\hline 130 & Tonga & NA & & 19.66 & $* *$ \\
\hline 131 & West Bank and Gaza & 19.00 & $* *$ & 19.00 & $* *$ \\
\hline 132 & Iraq & 14.73 & $* *$ & 19.00 & \\
\hline 133 & Bangladesh & 6.88 & $*$ & 18.70 & \\
\hline 134 & Cote d'Ivoire & 6.54 & $* *$ & 17.99 & $*$ \\
\hline 135 & Swaziland & 12.42 & $*$ & 17.72 & \\
\hline 136 & Nicaragua & 8.47 & $* *$ & 17.70 & $*$ \\
\hline 137 & Cambodia & 10.90 & $* *$ & 17.37 & $*$ \\
\hline 138 & Kenya & 5.89 & $*$ & 16.43 & $*$ \\
\hline 139 & Djibouti & 11.31 & $*$ & 16.08 & \\
\hline 140 & Yemen & 10.02 & $* *$ & 15.76 & $*$ \\
\hline 141 & Nigeria & 4.77 & $*$ & 14.72 & $*$ \\
\hline 142 & Ghana & NA & & 14.70 & \\
\hline 143 & Tajikistan & 8.94 & $*$ & 14.46 & \\
\hline 144 & Benin & 4.17 & $* *$ & 14.39 & $*$ \\
\hline 145 & Tuvalu & NA & & 14.12 & $* *$ \\
\hline 146 & Samoa & 12.63 & $* *$ & 13.78 & $*$ \\
\hline \hline 147 & Angola & 4.28 & $* *$ & 13.77 & $*$ \\
\hline 148 & Mauritania & 2.99 & $* *$ & 13.43 & $*$ \\
\hline 149 & Timor-Leste & NA & & 13.10 & $* *$ \\
\hline 150 & Guinea & 9.56 & $* *$ & 13.10 & $*$ \\
\hline 151 & Lao PDR & 3.63 & $* *$ & 12.80 & $*$ \\
\hline 152 & Cameroon & 12.55 & & 12.68 & \\
\hline 153 & Zambia & 6.83 & $*$ & 12.53 & $*$ \\
\hline 154 & Nepal & 3.30 & $*$ & 12.35 & \\
\hline 155 & Turkmenistan & 8.31 & $* *$ & 12.24 & $*$ \\
\hline 156 & Eritrea & 0.93 & $* *$ & 11.75 & \\
\hline 157 & Rwanda & 6.46 & $* *$ & 11.51 & $*$ \\
\hline 158 & Chad & NA & & 11.50 & $* *$ \\
\hline 159 & The Gambia & 8.05 & $* *$ & 11.37 & $*$ \\
\hline 160 & Papua New Guinea & 5.94 & $* *$ & 11.32 & $*$ \\
\hline 161 & Togo & 7.80 & $* *$ & 11.14 & $*$ \\
\hline & & & & & \\
\hline
\end{tabular}




\begin{tabular}{|l|l|r|r|r|c|}
162 & Tanzania & 4.94 & $*$ & 11.02 & $*$ \\
\hline 163 & Senegal & 4.69 & $* *$ & 10.99 & $*$ \\
\hline 164 & Vanuatu & 2.37 & $* *$ & 10.89 & $*$ \\
\hline 165 & Myanmar & 9.61 & $* *$ & 10.29 & $* *$ \\
\hline 166 & Congo & NA & & 9.95 & $* *$ \\
\hline 167 & Somalia & NA & & 9.84 & $* *$ \\
\hline 168 & Uganda & 4.23 & $*$ & 9.69 & \\
\hline 169 & Afghanistan & 4.87 & $* *$ & 9.18 & $*$ \\
\hline 170 & Burkina Faso & 2.96 & $* *$ & 8.93 & $*$ \\
\hline 171 & Zimbabwe & NA & & 8.85 & $* *$ \\
172 & Ethiopia & 1.33 & $*$ & 8.33 & \\
\hline 173 & Mozambique & 7.24 & & 8.19 & \\
\hline 174 & Solomon Islands & 2.59 & $* *$ & 7.91 & $*$ \\
\hline 175 & Madagascar & 2.10 & $*$ & 7.52 & \\
\hline 176 & Comoros & 3.94 & $* *$ & 7.00 & $*$ \\
\hline 177 & Dem. Rep. Congo & 4.07 & $* *$ & 6.61 & $*$ \\
\hline 178 & Malawi & 4.51 & $*$ & 6.50 & $*$ \\
\hline 179 & Lesotho & 4.70 & $*$ & 6.47 & $*$ \\
\hline 180 & Sao Tome and Principe & NA & & 6.33 & $*$ \\
\hline 181 & Central African Republic & 2.16 & $* *$ & 6.06 & $*$ \\
\hline 182 & Mali & 2.26 & $*$ & 5.87 & $*$ \\
\hline 183 & Burundi & 4.13 & $* *$ & 5.49 & $*$ \\
\hline 184 & Niger & 5.91 & $* *$ & 4.86 & $*$ \\
\hline
\end{tabular}

increased the international Internet bandwidth per user. A mostly European cluster with Belgium, France, Portugal, Austria and Germany follows with Australia, Singapore and Japan in between.

One is to expect distinct factors to emerge from the factor analysis. A KMO statistic is computed for each individual sub- indicator, and their sum is the overall KMO statistic. This statistic varies from 0 to 1.0 , and should be 0.60 or higher to proceed with factor analysis though realistically it should exceed 0.80 if the results of the principal component analysis are to be reliable. If not, it is recommended to drop the sub-indicators with the lowest individual KMO statistic values, until results rise above 0.60 .

\footnotetext{
${ }^{*}$ Missing 1 component

** Missing 2 components
}

Table A.4. presents data for all countries in the sample. 